\title{
PERTANGGUNGJAWABAN TERHADAP KONSUMEN ATAS IKLAN-IKLAN YANG MENYESATKAN DI ERA GLOBALISASI*
}

\author{
Oleh : \\ Anthon Fathanudien \\ Fakultas Hukum Universitas Kuningan \\ Email: anthon.fathanudien@gmail.com
}

\begin{abstract}
Advertising agency as an ad designer just concentrate on how to create ads that are satisfactory in accordance with client requests without trying to prove whether conveyed by the advertisements that correspond to reality or not.From the above description can be stated problems among other forms of accountability to consumers over misleading information in advertising and consumer efforts in tackling the impact of misleading advertising. So with the Law No. 8 of 1999 on Consumer Protection that any consumer harmed by business operators may file a lawsuit to businesses in the form of damages pursuant to Article 1365 Civil Code which acts against the law and Article 1243 of the Civil Code is about defaults.
\end{abstract}

\section{Key word : Pertanggungjawaban, Konsumen, Globalisasi}

\begin{abstract}
Abstrak
Biro iklan sebagai pendesain iklan hanya mengkonsentrasikan diri pada bagaimana membuat iklan yang memuaskan sesuai dengan permintaan kliennya tanpa berupaya membuktikan apakah yang disampaikan oleh iklan itu sesuai dengan kenyataannya atau tidak.Dari uraian di atas dapat dikemukakan permasalahan antara lain bentuk pertanggungjawaban terhadap konsumen atas informasi yang menyesatkan dalam dunia periklanan serta upaya konsumen dalam menanggulangi dampak iklan yang menyesatkan.Jadi dengan adanya Undang-undang Nomor 8 Tahun 1999 Tentang Perlindungan Konsumen yaitu setiap konsumen yang dirugikan oleh pelaku usaha dapat mengajukan gugatan kepada pelaku usaha berupa ganti rugi
\end{abstract}

- Artikel ini hasil penelitian hibah LBH Cirebon 2015 dengan Nomor 001/LBHCirebon/PBH/VI/2015. 
berdasarkan Pasal 1365 KUHPerdata yaitu perbuatan melawan hukum serta Pasal 1243 KUHPerdata yaitu tentang wanprestasi.

Kata Kunci: Pertanggungjawaban, Konsumen, Globalisasi.

\section{A. Pendahuluan}

Pembangunan nasional bertujuan untuk mewujudkan suatu masyarakat adil dan makmur yang merata materiil dan spritual dalam era demokrasi ekonomi berdasarkan Pancasila dan UndangUndang Dasar Negara Kesatuan Republik Indonesia 1945 ${ }^{1}$.Pembangunan perekonomian nasional pada era globalisasi harus dapat mendukung tumbuhnya dunia usaha, sehingga mampu menghasilkan beraneka barang dan atau jasa yang memiliki kandungan teknologi yang dapat meningkatkan kesejahteraan masyarakat banyak dan sekaligus mendapatkan kepastian atas barang dan atau jasa yang diperoleh dari perdagangan tanpa mengakibatkan kerugian konsumen.

Semakin terbukanya pasar nasional sebagai akibat dari proses globalisasi ekonomi harus tetap menjamin peningkatan kesejahteraan masyarakat serta kepastian atas mutu, jumlah dan keamanan barang dan atau jasa yang diperoleh di pasar. Untuk itu, dalam kehidupan bisnis, globalisasi digambarkan sebagai rangkaian yang saling terhubung antara berbagai perubahan-perubahan dalam aspek kehidupan masyarakat. Rangkaian perubahan ini menghasilkan suatu hal yang tidak dapat dibayangkan oleh masyarakat dunia sebelumnya, baik wujud maupun dampaknya.

1 Konsideran Undang-undang Nomor 8 Tahun 1999 Tentang Perlindungan Konsumen. 
Salah satu pelaku usaha dalam perekonomian yaitu produsen yang bertanggungjawab atas produksi dari barang dan jasa yang dihasilkannya. Pengusaha harus mampu menciptakan suatu produk yang berkualitas yang dapat diterima konsumen dan juga memiliki komitmen terhadap kualitas pelayanan kepada konsumen. Pengusaha dalam iklim persaingan ekonomi antar produsen yang begitu ketat akan berusaha menggunakan berbagai jalan dan cara untuk menyakinkan konsumen untuk memakai atau mengkonsumsi produknya dan mempengaruhi pasar seluas mungkin.Memang pelaku usaha atau produsen tidak bisa menghindari kekuatan ampuh produk iklan untuk menarik daya minat konsumen sebanyak mungkin selama hasrat dan kebutuhan manusia masih menginginkannya. Oleh karena itu, produsen perlu melakukan komunikasi langsung maupun tidak langsung dengan calon konsumen untuk mensosialisasikan ide-ide, produk barang dan atau jasa hasil produksinya yang dilakukan melalui media periklanan (advertising) baik media cetak maupun media elektronik.

Dahulu, ragam cara yang dilakukan seorang pelaku usaha baik produsen maupun distributor saat melakukan penawaran akan suatu produk baik barang maupun jasa sangat sederhana. Kesederhanaan ini lahir dari struktur masyarakat yang memang masih sederhana. Kini, ketika semua kesederhanaan tersebut telah bermetaformosis menjadi kehidupan dengan tingkat kompleksitas yang tinggi, para pelaku usaha pun bereaksi dengan menyesuaikan teknik penawaran dan pemasaran yang digunakannya.Para pelaku usaha kini harus saling berlomba-lomba dalam bersaing mendapatkan atensi konsumen untuk memilih produknya. Teknik-teknik beriklan dan 
memasarkan produk pun mulai bervariasi, bahkan diantaranya melahirkan cabang ilmu pengetahuan sendiri seperti social networking study, sebuah cabang ilmu yang mempelajari teknik pemasaran dengan menggunakan jaringan sosial. Media yang digunakan pun beragam, dari penggunaan TV, media cetak, brosur hingga elektronik melalui social media.

Promosi, khususnya yang dilakukan melalui iklan mempunyai fungsi yang cukup penting bagi konsumen. Tanpa iklan mungkin konsumen tidak akan pernah mengenal suatu barang maupun jasa sehingga iklan benar-benar berfungsi sebagai sumber informasi dan pendidikan yang tentu saja dengan catatan iklan tersebut jujur, sehat dan tidak bohong.Biro iklan sebagai pendesain iklan hanya mengkonsentrasikan diri pada bagaimana membuat iklan yang memuaskan sesuai dengan permintaan kliennya tanpa berupaya membuktikan apakah yang disampaikan oleh iklan itu sesuai dengan kenyataan atau tidak ${ }^{2}$. Oleh karena periklanan begitu masyarakat, seringkali periklanan mendapat sorotan secara luas tidak hanya berkenaan dengan periklanan dalam pemasaran tetapi juga berkenaan dengan dampaknya terhadap konsumen sebagai suatu sarana pemasaran yang dapat menimbulkan akses batas fungsi sesungguhnya yang bersifat negatif.

2 Husni Syawali dan Neni Sri Imaniyati, Hukum Perlindungan Konsumen, Mandar Maju, Bandung, 2000, hlm. 36 


\section{B. Perumusan Masalah}

Berdasarkan uraian latar belakang masalah di atas, maka yang menjadi rumusan masalah yang menjadi fokus kajian dalam penulisan ini adalah:

1. Bagaimanakah bentuk pertanggungjawaban bagi pelaku usaha periklanan apabila ada iklan yang menyesatkan dan tidak sesuai dengan kualitas barang dan jasa yang sebenarnya?

2. Upaya apakah yang dapat dilakukan oleh konsumen untuk menanggulangi dampak dari penayangan iklan yang menyesatkan di media massa?

\section{Metode Penelitian}

Metode penelitian yang digunakan oleh penyusun dalam pembahasan penelitian ini adalah metode yuridis normatif, yaitu metode yang mengkaitkan atau menghubungkan suatu peristiwa kejadian atau fakta iklan yang menyesatkan konsumen melalui media cetak maupun media elektronik dengan memperhatikan ketentuan hukum yang ada dan berlaku di Indonesia berdasarkan acuan yuridis melalui penelitian kepustakaan dan penelitian lapangan. Metode penelitian hukum, menurut Soerjono Soekanto adalah "suatu kegiatan ilmiah, yang di dasarkan pada metode, sistematika dan pemikiran tertentu, yang bertujuan mempelajari satu atau beberapa gejala hukum tertentu, dengan menganalisanya ${ }^{3}$.

3 Soerjono Soekanto, Pengantar Penelitian Hukum, ,UII Press, Jakarta, 2007, hlm.5. 


\section{Data dan Sumbernya:}

1. Data primer atau data empiris yaitu sumber data dari melakukan observasi dan data berupa keterangan-keterangan dari narasumber, antara lain pengusaha, pelaku usaha, masyarakat, akademisi dan praktisi hukum.

2. Data sekunder yang digunakan dalam penelitian ini, Penggunaan data sekunder ini karena memiliki beberapa keuntungan, yaitu ${ }^{4}$ :

a. Pada umumnya data sekunder dalam keadaan siap terbuat dan dapat dipergunakan dengan segera.

b. Baik bentuk maupun isi data sekunder, telah di bentuk dan disini oleh peneliti-peneliti terdahulu, sehigga peneliti kemudian, tidak mempunyai pengawasan terhadap pengumpulan, pengolahan, analisa, maupun konstruksi data.

c. Tidak terbatas oleh waktu maupun tempat.

Data sekunder, biasanya dibedakan menjadi tiga kategori, yaitu bahan hukum primer, bahan hukum sekunder dan bahan hukum tersier.

1) Bahan hukum primer, yaitu berupa ketentuan perundangundangan yang mengikat dan peraturan lainnya.

2) Bahan hukum sekunder, yaitu bahan-bahan yang menjelaskan bahan hukum primer, seperti hasil-hasil penelitian, teori, konsep pemikiran para ahli atau buku-buku yang berkorelasi dengan masalah yang di teliti. Dalam penyusunan penelitian ini, bahan hukum sekundernya, adalah buku-buku yang berkaitan langsung dengan masalah yang dikaji, pendapat para ahli, teori-teori yang 
terkait dengan masalah yang diteliti, serta putusan-putusan pengadilan tentang kasus yang telah terjadi dalam masyarakat.

3) Bahan hukum tersier, yaitu bahan yang menjelaskan bahan hukum primer dan sekunder sepertinya kamus hukum.

\section{Pembahasan}

Pasal 28 UUD 1945 menyatakan bahwa "kemerdekaan berserikat dan berkumpul, mengemukakan pikiran dengan lisan dan tulisan dan sebagainya ditetapkan dengan undang-undang"5. Penjelasan pasal ini menyatakan tentang kedudukan warga negara yang memuat hasrat bangsa Indonesia untuk membangun negara yang bersifat demokratis dan yang hendak menyelenggarakan keadilan dan sosial dan perikemanusiaan". Kata-kata "dan sebagainya" membuat pasal ini tidak hanya terbatas pada kemerdekaan berserikat, berkumpul dan mengeluarkan pendapat secara lisan dan tulisan. Hak-hak lain yang secara tegas tidak disebutkan oleh pasal ini sebenarnya secara implisit terkandung di dalam kata-kata "dan sebagainya".

Untuk mencapai tujuan negara Indonesia sebagaimana termuat dalam pembukaan UUD 1945 alinea ke-4 menyatakan bahwa untuk memajukan kesejahteraan umu, mencerdaskan kehidupan bangsa dan ikut melaksanakan ketertiban duniayang berdasarkan kemerdekaan, perdamaian abadi dan keadilan sosial. Dalam TAP MPR No.II/MPR/1993 tentang GBHN ditetapkan bahwa perdagangan dalam negeri dan distribusi diarahkan untuk memperlancar arus

5 Pasal 28 Undang-Undang Dasar Negara Republik Indonesia Tahun 1945. Ibid. 
barang dan jasa serta melindungi kepentingan produsen dan konsumen, mempercepat pembangunan, menyebarkan dan memeratakan hasil pembangunan ke seluruh tanah air sehingga kesempatan usaha dan lapangan kerja terbuka lebih luas serta lebih mendorong peningkatan pendapatan masyarakat dan kesejahteraan rakyat $^{7}$. Dari uraian di atas, nampak pemerintah telah menetapkan bahwa perlindungan konsumen merupakan bagian dari pembangunan nasional.

Perlindungan konsumen yang dimaksud dalam penulisan ini adalah mengenai posisi konsumen secara hukum, dalam hal yang berkaitan dengan kegiatan periklanan yang dilakukan oleh pelaku media massa yang didasarkan pada hak dan kewajiban kedua belah pihak dengan memperhatikan ketentuan tentang periklanan dan menganalisisnya berdasarkan Undang-undang Nomor 8 Tahun 1999 Tentang Perlindungan Konsumen.Iklan atau advertisingdapat diartikan sebagai pesan yang menawarkan suatu produk yang ditujukan kepada masyarakat lewat suatu media massa. Namun pengertian iklan yang dimaksud dalam penulisan ini dititikberatkan kepada iklan yang menyesatkan konsumen yaitu suatu iklan yang mengakibatkan pandangan atau pikiran konsumen keliru dan salah mengenai produk yang diiklankan sehingga pada akhirnya merugikan kepentingan konsumen itu sendiri ${ }^{8}$.

Dalam kode etik periklanan yang dimaksud usaha periklanan terdapat beberapa istilah-istilah sebagai berikut ${ }^{9}$ :

TAP MPR RI No.II/MPR/1993 tentang GBHN.

M. Jamiludin Ritongga, "Kriteri-kriteria iklan yang menyesatkan", Suara Pembaharuan, 16 Maret 1999.

9 Jefkins Frank, Periklanan, Erlangga, Jakarta, 2000, hlm 12. 
1. Pengiklan yaitu perusahaan yang memesan iklan untuk mempromosikan, memasarkan, dan atau menawarkan produk yang mereka edarkan.

2. Perusahaan iklan adalah perusahaan atau biro yang bidang usahanya merupakan mendesaian atau membuat iklan untuk para pemesannya.

Sebelum lahirnya Undang-undang Nomor 8 Tahun 1999 Tentang Perlindungan Konsumen, untuk mengatur terjadinya pelanggaran akibat perbuatan pelaku usaha periklanan dari penayangan iklan yang menyesatkan di media cetak dan elektronik, konsumen dapat melakukan upaya berdasarkan perbuatan melawan hukum dalam Pasal 1365 KUHPerdata dan juga berdasarkan wanprestasi menurut Pasal 1243 KUHPerdata.

Usaha melindungi konsumen pertama-tama harus dilakukan melalui hukum. Harus diciptakan peraturan hukum untuk melindungi konsumen serta tanggung jawab pelaku usaha atau produsen. Berdasarkan pertimbangan tersebut di atas, maka diperlukan perangkat peraturan perundang-undangan untuk mewujudkan perlindungan kepentingan konsumen dan pelaku usaha sehingga tercipta perekonomian yang sehat. Secara yuridis, hubungan hukum dan atau masalah di antara pelaku usaha periklanan yaitu pengiklan, perusahaan iklan dan media massa terjadi melalui suatu perjanjian yang diatur dan masih tetap berlaku sebagaimana yang termuat dalam Buku III KUHPerdata. Menurut kode etik periklanan ${ }^{10}$ menegaskan bahwa iklan itu harus jujur, bertanggung jawab dan

Kode Etik Periklanan. 
tidak bertentangan dengan hukum yang berlaku. Setiap iklan yang ditayangkan harus dijiwai dengan rasa persaingan yang sehat.

Undang-undang Perlindungan Konsumen pada dasarnya dilatarbelakangi oleh konsumen dan pelaku usaha yang pada praktiknya tidak seimbang. Posisi pelaku usaha yang menawarkan, menjual dan mempromosikan produknya menjadikan dirinya lebih kuat dibanding konsumen ${ }^{11}$. Hal ini bisa terjadi, bisa ditunjang dari kebutuhan informasi pada saat tahap pra transaksi, sedikitnya pilihan atas produk-produk lain, keterbatasan pengetahuan, promosi produk yang membingungkan dan kemampuan pendidikan konsumen untuk mencerna kalimat-kalimat reklame dan lain-lain menyebabkan posisi konsumen terhadap pelaku usaha semakin melemah.

Menurut hasil penelitian Badan dan Pembinaan Hukum Nasional, faktor-faktor yang melemahkan konsumen, antara lain ${ }^{12}$ :

1. Masih rendahnya kesadaran konsumen akan haknya, sehingga tidak timbul kemauan untuk menuntut hak.

2. Proses peradilan yang ruwet, berliku dan memakan waktu yang berkepanjangan.

3. Posisi konsumen yang memang sudah lemah, akibat perbuatan pelaku usaha.

4. Politik pembangunan negara yang meleluasakan pelaku usaha terjadinya ketidakseimbangan.

5. Tidak konsistennya badan peradilan atas putusan-putusan yang ada

6. Sistem dan produk hukum yang masih belum menjamah dalam hal perumusan kebijakan perlindungan konsumen.

11 N.H.T. Siahaan, Hukum Konsumen : Perlindungan Konsumen dan Tanggung Jawab Produk, Panta Rei, Jakarta, 2005, hlm. 36. 
Selanjutnya masalah yang muncul dan menjadi penghambat dalam perkembangan periklanan di Indonesia dapat dikelompokkan menjadi beberapa faktor yaitu :

1. Faktor Konsumen : masih rendahnya taraf kesadaran dari konsumen yaitu masih adanya sikap kurang responsive yang tidak mendukung pelaksanaan perlindungan konsumen, seperti sikap tak acuh terhadap hak-hak konsumen, apatis atau pendidikan pengetahuan yang kurang mengenai produk barang dan atau jasa yang dikonsumsi, masih rendahnya tingkat pendapatan masyarakat yang berpenghasilan menengah ke bawah yang berpengaruh kepada keengganan konsumen untuk menuntut ganti rugi. Oleh karena biaya untuk beracara di Pengadilan cukup besar terutama bagi konsumen berpenghasilan rendah, sehingga konsumen memilih sikap diam dan tidak lagi menggunakan produk yang dapat merugikan konsumen.

2. Faktor Pelaku Usaha Periklanan : permasalahan yang timbul dari pihak pelaku perusahaan periklanan adalah adanya sikap yang tidak mengerti akan pentingnya perlindungan konsumen dalam periklanan. Banyak pelaku usaha menganggap perlindungan konsumen hanya akan menambah biaya produksi saja. Kepentingan pelaku usaha hanyalah memasarkan produksi seluas-luasnya kepada masyarakat diantaranya melalui penayangan iklan di media massa. Di samping itu, beberapa pelaku usaha yang mempunyai keterbatasan penggunaan teknologi untuk menghasilkan produk-produk yang yang memenuhi persyaratan dapat menimbulkan kerugian kepada konsumen. Hak-hak konsumen seringkali diabaikan oleh pelaku usaha yang menawarkan barang dan atau jasa melalui iklan dengan prinsip asal murah, asal jadi, anggaran untuk iklan lebih dianggap sebagai biaya produksi dan bukan sebagai investasi. Demikian pula sikap perusahaan iklan yang membuat iklan asal jadi atau bahkan ada yang menganggap peraturan periklanan hanya akan menghambat kreativitas pembuatan iklan. 
3. Faktor Lembaga Konsumen : lembaga konsumen adalah lembaga yang bertujuan memberikan bimbingan dan perlindungan bagi konsumen untuk mencapai kesejahteraan terutama konsumen yang merasa dirugikan sebagai akibat dari penggunaan, pemanfaatan produk serta pemakaian atas produk yang dihasilkan oleh pelaku usaha tertentu. Permasalahan atau kendala yang dihadapi oleh lembaga konsumen pada umumnya adalah keterbatasan dana dan sarana yang menunjang kegunaan operasional lembaga tersebut. Penelitian dan pengujian produk di pasaran belum dapat dilakukan karena lembaga konsumen seperti Yayasan Bina Konsumen Indonesia, Yayasan Lembaga Konsumen Indonesia belum memiliki laboratorium sendiri. Keterbatasan jumlah tenaga pengurus atau sukarelawan pada lembaga konsumen juga menjadi penghambat usaha perlindungan konsumen. Pada umumnya tenaga pengurus pada lembaga konsumen terikat dengan pekerjaan lain sehingga kesempatan atau waktu untuk berkiprah pada lembaga konsumen kurang optimal.

4. Faktor Pemerintah : pemerintah sebagai instansi yang berwenang menangani perlindungan konsumen khususnya mengenai periklanan pada umumnya menganggap adanya perlindungan konsumen dalam periklanan. Namun demikian, dalam pelaksanaannya seringkali tanggapan atau tindakan pemerintah lambat atau tidak memuaskan konsumen dengan berbagai alasan. Dengan lahirnya Undang-undang Nomor 8 Tahun 1999 tentang Perlindungan Konsumen yang bertujuan untuk melindungi kepentingan konsumen. Oleh karena itu, undang-undang perlindungan konsumen dapat dijadikan landasan hukum yang kuat bagi konsumen, pemerintah, dan Lembaga Perlindungan Konsumen Swadaya Masyarakat untuk melakukan perlindungan konsumen. Namun sampai saat ini, ternyata hal tersebut belum dapat ditetapkan dan dilaksanakan. Contohnya belum terdapat upaya yang serius dari pihak pemerintah untuk segera mewujudkan dan membentuk Badan Perlindungan Konsumen Nasional untuk membantu upaya pengembangan perlindungan konsumen dan membentuk Badan Penyelesaian Sengketa Konsumen yang bertugas 
menangani dan menyelesaikan sengketa antara pelaku usaha dengan konsumen.

Periklanan merupakan salah satu sarana pemasaran dan sarana penerangan yang memegang peranan penting dalam pembangunan bangsa Indonesia, maka dari itu suatu iklan harus mengandung unsur-unsur :

1. Iklan harus jujur, bertanggung jawab dan tidak bertentangan dengan hukum yang berlaku.

2. Iklan tidak menyinggung perasaan dan atau merendahkan martabat, agama, tata susila, adat, budaya, suku dan golongan.

3. Iklan harus dijiwai dan didasarkan dengan asas rasa persaingan yang sehat.

Dengan adanya dan diundangkannya Undang-undang Perlindungan Konsumen, diharapkan mampu mewujudkan perlindungan hukum bagi konsumen terhadap para pelaku usaha yang bertindak curang dalam memproduksi iklan.

\section{Bentuk tanggung jawab bagi pelaku usaha periklanan}

Dalam hal tanggung jawab pelaku usaha maka perlu dilihat ada tidaknya suatu kerugianyang telah di derita oleh konsumen sebagai akibat dari penggunaan, pemanfaatan, serta pemakaian atas produk yang dihasilkan oleh pelaku usaha tertentu. Tanggung jawab pelaku usaha dalam Undang-undang Perlindungan Konsumen mengandung materi yang berstruktur sebagai berikut ${ }^{13}$ :

\section{Product Liability}

Johannes Gunawan, Tanggung Jawab Pelaku Usaha Menurut Undang-undang Nomor 8 Tahun 1999 Tentang Perlindungan Konsumen, Jurnal Hukum Bisnis, 2001, hlm 47. 
Product Liability adalah tanggung jawab perdata secara langsung dari pelaku usaha atas kerugian yang dialami akibat mengkonsumsi produk yang dihasilkannya.

\section{Profesional Liability}

Profesional Liability adalah tanggung jawab perdata yang didasarkan pada tanggung jawab perdata secara langsung atas dasar perjanjian kontrak dari pelaku usaha pemberi jasa atas kerugian yang dialami oleh konsumen akibat memanfaatkan jasa yang diberikannya.

\section{Contractual Liability}

Contractual Liability adalah tanggung jawab perdata atas dasar perjanjian dari pelaku usaha baik terhadap barang maupun jasa yang dihasilkannya atas kerugian yang dialami konsumen akibat mengkonsumsi barang yang dihasilkannya atau memanfaatkan jasa yang diberikannya.

4. Criminal Liability

Criminal Liability adalah tanggung jawab pidana dari pelaku usaha atas terganggunya keselamatan dan keamanan konsumen.

Pada umumnya, konsumen mengetahui iklan sebagai sumber informasi dari media massa dan tidak mengetahui tentang proses pembuatan iklan serta benar atau tidaknya isi dari iklan tersebut. karena itu sangat berat bagi konsumen untuk untuk membuktikan suatu kesalahan atau pelanggaran yang dilakukan pelaku usaha periklanan. Merupakan hal yang wajar, apabila pelaku usaha periklanan dibebani beban pembuktian suatu produk yang menimbulkan kerugian harta benda, cacat tubuh atau bahkan kematian konsumen. 
Dalam pelanggaran praktek periklanan terkait instrumen hukum yang berupa kejelasan norma hukum di bidang periklananyaitu melarang penggunaan iklan yang disampaikan dengan cara $^{14}$ :

1. Mengemukakan hal-hal yang tidak benar

2. Mengemukakan hal-hal yang menyesatkan atau tidak proporsional

3. Menggunakan opini subyektif berlebihan tanpa didukung fakta.

Dalam sistem pertanggungjawaban seperti ini dirasakan kurang tepat bila diterapkan di bidang periklanan karena tidak ada hubungan atas bawah diantara pelaku usaha periklanan. Artinya pengiklan, perusahaan iklan dan media massa memiliki kedudukan yang sama dan berdiri sendiri serta tidak ada hubungan atas bawah. Dalam keadaan tertentu dapat saja media massa sekaligus juga berperan sebagai perusahaan iklan.Sehubungan dengan hal tersebut, maka konsumen dapat meminta pertanggungjawaban kepada pelaku usaha tanpa harus mengetahui siapa yang bertanggung jawab diantara ketiganya karena yang terpenting bagi konsumen adalah memperoleh ganti rugi akibat iklan yang menyesatkan tersebut. setiap komponen pemasaran, pengiklan, perusahaan iklan dan media periklanan mempunyai tanggung jawab menurut peran dan bobot keterlibatan masing-masing dalam penciptaan dan penyebaran pesan-pesan iklan yaitu ${ }^{15}$ :

1. Pengiklan, yaitu bertanggung jawab atas benarnya informasi tentang produk yang diberikan kepada perusahaan periklanan dan termasuk ikut memberi arah, batasan dan masukan pada

14 Yusuf Shofie, Perlindungan Konsumen dan Instrumen-instrumen Hukum, Citra aditya, Bandung, 2002, hlm 147.

15 Dedi Harianto, Perlindungan hukum bagi Konsumen Terhadap Iklan yang Menyesatkan, Ghalia, Bogor, 2010, hlm. 32. 
pesan iklan sehingga tidak terjadi janji yang berlebihanatas kemampuan yang nyata dalam produk.

2. Perusahaan iklan, adalah bertanggung jawab atas ketepatan unsur persuasi yang dimaksudkan dalam pesan iklan melalui pemilahan dan pemilihan informasi yang diberikan pengiklan maupun dalam upaya menggali dan mendayagunakan kreatifitasnya.

3. Media periklanan, yaitu bertanggung jawab atas kesepadanan antara pesan iklan yang disiarkannya dengan nilai-nilai sosial dan budaya dari sasarannya.

Iklan berpotensi menimbulkan kerugian bagi masyarakat pada umumnya dan konsumen pada khususnya, maka perlu dipertimbangkan pentingnya realisasi pertanggungjawaban pelaku usaha atas perilaku merugikan tersebut. Secara garis besar, pertanggungjawaban pelaku usaha ini bisa muncul terkait dengan dua hal berikut, yaitu ${ }^{16}$ :

1. Informasi produk yang disajikan melalui iklan tidak sesuai dengan kenyataan yang sebenarnya.

Dalam hal ini, yang bertanggungjawab pengiklan (produsen), karena menyangkut suatu produk yang dijanjikan kepada konsumen melalui iklan. Dengan instrumen hukum perdata, konsumen dapat meminta pertanggungjawaban pelaku usaha didasarkan pada product liability.

2. Menyangkut kreativitas perusahaan periklanan dan atau media periklanan ternyata bertentangan dengan asas-asas etika periklanan.

Dalam hal ini, yang bertanggungjawab adalah pengiklan serta perusahaan iklan dan atau media massa. Ketiga pelaku usaha di atas, dapat dimintakan pertanggungjawaban secara tanggung jawab renteng apabila iklan yang ditayangkan menyesatkan konsumen, mengingat dalam peristiwa tersebut yang melakukannya tidak hanya seorang atau satu pihak saja.

16 Yusuf Shofie, Sistem Tanggung Jawab dalam Periklanan, Jurnal Hukum dan Pembangunan No. 2 Tahun XXVI April 1996, hlm 142. 
Dalam proses terjadinya iklan, baik melalui media massa baik media cetak maupun media elektronika, pada umumnya inisiatif dari pengiklan (produsen, distributor, suplier dan retailer). Kemudian perusahaan iklan dan atau media dengan persetujuan pengiklan secara kreatif menterjemahkan inisiatif tadi dalam bahasa periklanan untuk ditayangkan atau dimuat dalam media sebagai informasi produk bagi masyarakat konsumen luas.

\section{Upaya yang dapat dilakukan konsumen untuk menanggulangi dampak dari penayangan iklan yang menyesatkan di media massa}

Salah satu pelaku usaha dalam perekonomian yaitu produsen yang bertanggungjawab atas produksi dari barang dan jasa yang dihasilkannya. Dalam memasuki era perkembangan globalisasi, pengembangan usaha sangat berkaitan dengan ketepatan dalam membuat usaha atau produk (barang atau jasa) yang sesuai dengan kebutuhan konsumen dan sesuai dengan kebutuhan pasar mendatang. Pengusaha harus mampu untuk menciptakan suatu produk yang berkualitas yang dapat diterima konsumen dan juga memiliki komitmen terhadap kualitas pelayanan kepada konsumen. Pengusaha dalam dunia iklim persaingan ekonomi antar produsen yang begitu ketat akan berusaha menggunakan berbagai jalan dan cara untuk menyakinkan konsumen untuk memakai atau mengkonsumsi produknya dan mempengaruhi pasar seluas mungkin. Memang pelaku usaha atau produsen tidak bisa menghindari kekuatan ampuh produk iklan untuk menarik daya minat konsumen sebanyak mungkin selama hasrat dan kebutuhan manusia masih 
menginginkannya. Oleh karena itu, produsen perlu melakukan komunikasi langsung maupun tidak langsung dengan calon konsumen untuk mensosialisasikan ide-ide, produk barang dan jasa hasil produksinya yang dilakukan melalui media periklanan baik media cetak maupun elektronika.

Media massa sebenarnya merupakan rangkaian proses periklanan. Dalam hal tersebut, para pelaksana media massa baik cetak maupun elektronik dituntut lebih selektif dan tidak sembarangan memuat iklan yang bertentangan dengan ketentuan peraturan perundang-undangan tentang periklanan. Dengan demikian, seharusnya iklan yang menyesatkan tidak perlu ada karena sudah terseleksi oleh pelaksana media massa.

Mengenai keunggulan dan kelemahan iklan di media cetak sebagai berikut ${ }^{17}$ :

1. Keunggulan

a. Iklan di media cetak merupakan sarana yang paling murah bagi para pelaku usaha untuk mendapatkan sejumlah calon pembeli baik di kota, pedesaan, bahkan di luar negeri.

b. Iklan dapat dipasang dengan cepat dibandingkan dengan waktu yang diperlukan untuk membuat iklan di media elektronik.

c. Iklan dapat ditargetkan kepada orang tertentu dengan menggunakan surat kabar atau majalah yang biasa mereka baca.

d. Surat kabar dan majalah mempunyai kapasitas yang besar untuk menampung iklan dibandingkan dengan waktu yang tersedia untuk iklan di televisi atau radio.

Jefkins Frank, Periklanan, Erlangga, Jakarta, 2000, hlm 97. 
e. Dapat dibaca berulang kali. Beberapa publikasi seperti majalah dapat bertahan lama, dapat disimpan, mudah diarsipkan atau diberikan kepada pembaca (calon konsumen) yang lain.

f. Iklan atas produk barang atau jasa tertentu sering dikelompokkan bersama-sama sehingga seorang pengiklan tidak perlu mengeluarkan banyak biaya untuk mengiklankan produksinya. Ia cukup membeli satu ruang yang kecil saja.

2. Kelemahan

a. Banyaknya media cetak terutama surat kabar yang sulit dibaca atau penampilannya kurang menarik dan banyak terjadi kesalahan cetak.

b. Tidak memiliki kesan hidup karena tidak dilengkapi dengan realitas suara, gerak dan warna bergerak seperti iklan di televisi bahkan sekedar realitas suara saja seperti iklan di radio.

c. Sepanjang hari terdapat liputan berita di televisi dan radio sehingga mereka dapat menampilkan berita yang lebih hangat daripada berita di media cetak yang hanya muncul sekali dalam sehari, sekali dalam seminggu, ataupun sehari dalam sebulan.

d. Adanya keenggana membaca apalagi yang hendak dibaca adalah artikel yang berat.

Selanjutnya keunggulan dan kelemahan iklan di media elektronik sebagai berikut ${ }^{18}$ :

1. Keunggulan

Ibid, hlm 99. 
a. Media elektronik merupakan suatu sarana iklan yang hidup dan lebih menarik karena dilengkapi dengan kombinasi warnawarna, suara, dan gerakan seperti iklan di televisi dan penggunaan suara baik vokal maupun musik seperti iklan di radio.

b. Bisa ditayangkan hingga beberapa kali dalam sehari sampai dipandang cukup bermanfaat yang memungkinkan sejumlah masyarakat untuk menyaksikan dan mendengarkannya dan frekuensi yang cukup sehingga pengaruh iklan itu bangkit.

c. Program radio atau televisi biasanya disiarkan atau ditayangkan setiap hari bahkan banyak yang mengudara 24 jam non stop.

d. Banyak pengiklan memandang media cetak dan media elektronik sebagai media periklanan yang paling efektif untuk menyampaikan pesan komersialnya karena kemampuannya yang menjangkau khalayak sasaran yang sangat luas terutama televisi.

e. Iklan di televisi disiarkan di rumah-rumah dalam suasana yang serba santai atau rekreasi bagi masyarakat sehingga perhatian terhadap iklan di televisi lebih besar. Sedangkan banyak orang mendengarkan radio untuk meresepsi rasa sepi dan menimbulkan kesan bahwa disampingnya ada sahabat yang setia.

2. Kelemahan

a. Media elektronik cenderung menjangkau pemirsa secara massal sehingga pemilihan (untuk kepentingan, pembidikan pangsa pasar) sering sulit dilakukan. Pihak pengiklan akan 
dapat lebih selektif dalam membidik pasar yang dikehendaki kalau ia menggunakan media cetak.

b. Jika yang diperlukan calon pembeli adalah data yang lengkap mengenai suatu produk atau perusahaan pembuatnya maka televisi dan radio tidak akan bisa menandingi media cetak.

c. Hal-hal kecil lainnya bisa dan biasanya dikerjakan banyak orang sambil menonton televisi, sama seperti ketika mereka mendengarkan radio yang berakibat konsentrasi mereka seringkali pecah.

Dalam usaha meraih calon konsumen melalui iklan maka seringkali pelaku usaha kurang peduli akan hak sebagai konsumen yaitu hak atas informasi sehingga dapat merugikan konsumen atau masyarakat untuk membeli produk tersebut. Dengan adanya hal tersebut, upaya-upaya yang dapat dilakukan konsumen akibat penayangan iklan yang menyesatkan adalah sebagai berikut :

1. Penyelesaian secara langsung kepada pelaku usaha periklanan Konsumen dapat secara langsung meminta keterangan penyelesaian terhadap iklan di media massa kepada pelaku usaha periklanan yaitu pengiklan. Dengan mencoba menyelesaikan kasus sendiri berarti konsumen telah menerapkan hak dan kewajibannya. Disamping itu juga menunjukkan sikap kritis konsumen terhadap pelaku usaha.

2. Penyelesaian melalui YLKI

Apabila penyelesaian secara langsung tidak berhasil, maka konsumen dapat mengadukan ke YLKI. Untuk pengaduan konsumen kepada YLKI, ada beberapa cara yang dapat dilakukan yaitu antara lain : 
a. Langsung secara lisan

Konsumen datang langsung ke kantor YLKI untuk mengadukan permasalahannya dengan menyertakan bukti-bukti yang diperlukan.

b. Melalui surat

Konsumen dapat mengirim surat keluhannya kepada YLKI dengan disertai barang bukti yang ada.

c. Melalui telepon

YLKI juga menerima pengaduan konsumen melalui telepon

d. Melalui media massa

Pengaduan konsumen melalui media massa juga diperlukan dan

YLKI akan membantu menyelesaikannya.

Setiap pengaduan yang diterima YLKI akan diteliti kebenarannya terlebih dahulu. Hal ini dimaksudkan sebagai bukti bahwa pembelaan YLKI terhadap konsumen bukan dilandasi oleh keinginan untuk menjatuhkan suatu perusahaan atau pelaku usaha tetapi untuk menegakkan kebenaran dan membela konsumen yang dirugikan. Setelah pengaduan dinyakini kebenarannya dan konsumen tidak mengada-ngada maka pengaduan tersebut siap untuk diselesaikan. Banyak cara yang ditempuh dan cara mana yang digunakan tergantung pada jenis dan sifat pengaduannya.

Beberapa cara penyelesaian pengaduan yang ditempuh YLKI adalah sebagai berikut :

a. Pengaduan diselesaikan dengan cara menghubungi toko, penjual, atau pelaku usaha.

b. Pengaduan diselesaikan dengan cara penelitian laboratorium. 
c. Pengaduan diselesaikan dengan menghubungi instansi yang berwenang.

d. Pengaduan diselesaikan dengan cukup memberikan penjelasan kepada pengadu.

e. Pengaduan diselesaikan dengan cara ke Pengadilan.

Dalam Undang-undang Perlindungan Konsumen memberikan alternatif penyelesaian melalui badan di luar sistem peradilan yang disebut dengan Badan Penyelesaian Sengketa Konsumen (BPSK), selain melalui Pengadilan Negeri yang daerah hukumnya meliputi tempat kedudukan konsumen. Terdapat beberapa ketentuan yang diatur dalam Bab XI Undang-undang Perlindungan Konsumen mengenai BPSK, ada dua hal pokok yang dapat dikemukakan di sini yaitu:

a. Penyelesaian sengketa di luar pengadilan melalui BPSK bukanlah suatu keharusan untuk ditempuh konsumen sebelum pada akhirnya sengketa tersebut diselesaikan melalui lembaga peradilan. Walaupun demikian, hasil putusan BPSK memiliki daya hukum yang cukup untuk memberikan peringatan bagi pelaku usaha yang nakal karena putusan tersebut dapat dijadikan bukti bagi penyidik. Selain tugas tersebut, BPSK bertugas untuk menjatuhkan sanksi administratif terhadap pelaku usaha yang melanggar larangan-larangan tertentu yang dikenakan bagi pelaku usaha dan BPSK juga dalam memutuskan pelaksanaan atau penerapan eksekusinya harus meminta keputusannya dari Pengadilan.

b. Undang-undang Perlindungan Konsumen menyatakan gugatan atas pelanggaran pelaku usaha dapat dilakukan oleh seorang konsumen yang dirugikan ahli waris yang bersangkutan, sekelompok 
konsumen, swadaya masyarakat yang memenuhi syarat dari pemerintah hanya dapat diajukan kepada peradilan umum.

Selain itu, Undang-undang Perlindungan Konsumen telah memberikan jangka waktu yang pasti dalam penyelesaian perselisihan konsumenyang timbul yakni 21 (dua puluh) hari untuk proses pada tingkat Pengadilan Negeri dan 30 (tiga puluh) hari untuk diselesaikan oleh Mahkamah Agung dengan jangka waktu masing-masing 14 (empat belas) hari untuk mengajukan keberatan ke Pengadilan Negeri maupun kasasi ke Mahkamah Agung.

Aturan mengenai sanksi-sanksi yang dapat dikenakan kepada pelaku usaha yang melanggar ketentuan dapat ditemukan dalam Undang-undang Nomor 8 Tahun 1999 Tentang Perlindungan Konsumen BAB XIII yang dimulai dari Pasal 60 sampai dengan Pasal 63. Sanksi-sanksi yang dapat dikenakan berupa yaitu ${ }^{19}$ :

\section{Sanksi Administratif}

Sanksi administratif diatur dalam Pasal 60 Undang-undang Perlindungan Konsumen. Sanksi administratif ini merupakan suatu "hak khusus" yang diberikan oleh Undang-undang Perlindungan Konsumen kepada Badan Penyelesaian Sengketa Konsumen (BPSK) atau tugas dan atau kewenangan yang diberikan untuk menyelesaikan persengketaan konsumen di luar Pengadilan. Menurut ketentuan Pasal 60 ayat 1 jo Pasal 60 ayat 2 Undang-undang Perlindungan Konsumen, sanksi administratif yang dapat dijatuhkan adalah berupa penetapan ganti rugi sampai setinggi-tingginya Rp.200.000.000 (dua ratus juta rupiah) terhadap para pelaku usaha

19 Undang-undang Nomor 8 Tahun 1999 tentang Perlindungan Konsumen. 
periklanan yang melakukan pelanggaran karena terjadinya kerugian sebagai akibat kegiatan promosi iklan.

2. Sanksi pidana pokok

Sanksi pidana pokok adalah sanksi yang dapat dikenakan dan dijatuhkan oleh pengadilan atas tuntutan jaksa penuntut umum terhadap pelanggaran yang dilakukan oleh pelaku usaha periklanan.

Rumusan dalam Pasal 62 Undang-undang Perlindungan Konsumen menentukan bahwa pelaku usaha dan atau pengurus yang melakukan pelanggaran terhadap :

a. Ketentuan sebagaimana dimaksud dalam :

1). Pasal 7, Pasal 8, Pasal 9, Pasal 10 Undang-undang Perlindungan Konsumen mengenai informasi yang tidak benar;

2).Pasal 17 ayat 1 huruf $a$, huruf $b$, huruf $c$ dan huruf e Undangundang Perlindungan Konsumen mengenai iklan yang memuat informasi yang tidak sesuai dengan kenyataan atau menyesatkan;

3). Pasal 17 ayat 2 Undang-undang Perlindungan Konsumen mengenai peredaran iklan yang dilarang.

Dapat dikenakan sanksi pidana dengan pidana penjara paling lama 5 (lima) tahun atau pidana denda sebanyak Rp. 2.000.000.000 (dua milyar rupiah).

b. Ketentuan sebagaimana dimaksud dalam :

1). Pasal 12 Undang-undang Perlindungan Konsumen mengenai penawaran dengan tarif khusus;

2). Pasal 13 ayat 1 Undang-undang Perlindungan Konsumen mengenai pemberian hadiah secara cuma-cuma; 
3). Pasal 17 ayat 1 huruf $d$ dan huruf $f$ Undang-undang Perlindungan Konsumen mengenai produksi iklan yang bertentangan dengan etika, kesusilaan, dan ketentuan hukum yang berlaku dan dapat dipidana paling lama 2 tahun atau pidana denda paling banyak Rp. 500.000.000 (lima ratus juta rupiah).

c. Pelanggaran yang mengakibatkan luka berat, cacat, cacat tetap, atau kematian maka akan diberlakukan ketentuan pidana yang berlaku secara umum.

3. Sanksi pidana tambahan

Ketentuan Pasal 63 Undang-undang Perlindungan Konsumen memungkinkan diberikannya sanksi pidana tambahan diluar sanksi pidana pokok yang dapat dijatuhkan berdasarkan ketentuan Pasal 62 Undang-undang Perlindungan Konsumen. Sanksi pidana tambahan dapat dijatuhkan berupa :

a. Perampasan barang tertentu;

b. Pengumuman keputusan hakim;

c. Pembayaran ganti rugi;

d. Perintah penghentian kegiatan tertentu yang menyebabkan timbulnya kerugian konsumen;

e. Kewajiban penarikan barang dari peredaran;

f. Pencabutan izin usaha.

Ketentuan Pasal 22 Undang-undang Perlindungan Konsumen memberikan beban dan tanggung jawab pembuktian pidana mengenai kesalahan dalam setiap pelanggaran yang dilakukan oleh pelaku usaha periklanan kepada konsumen sepenuhnya. Walaupun demikian, 
Undang-undang Perlindungan Konsumen tidak menutup kemungkinan dilakukannya oleh jaksa penuntut umum.

Ketentuan ini memperjelas bahwa Badan Penyelesaian Sengketa Konsumen (BPSK) tidak memiliki kewenangan untuk menjatuhkan sanksi atas setiap pelanggaran yang dilakukan oleh pelaku usaha. Ini sejalan dengan ketentuan Pasal 47 Undang-undang Perlindungan Konsumen yang menyatakan bahwa penyelesaian sengketa di luar pengadilan diselenggarakan untuk mencapai kesepakatan mengenai tindakan tertentu untuk menjamin tidak terjadi kembali atau tidak akan terulang kembali kerugian yang akan diderita konsumen.

Berjalan tidaknya sanksi-sanksi yang telah ditentukan tersebut sangat bergantung pada siap tidaknya berbagai pihak yang terkait. Di samping itu, kemampuan dan pengetahuan yang cukup signifikan tentang perlindungan konsumen juga sangat penting untuk meningkatkan efektifitas pelaksanaan Undang-undang perlindungan konsumen ini dalam praktek.

\section{E. Penutup}

\section{a. Kesimpulan}

Globalisasi memegang peranan penting dalam segala perubahan dalam dunia perekonomian, termasuk terhadap aspek periklanan yang merupakan bagian dari transaksi jual beli antara konsumen dan pelaku usaha. Tingginya persaingan antar pelaku usaha yang diakibatkan oleh dampak dari globalisasi tersebut, membuat para pelaku usaha harus saling berlomba untuk memenangkan pasar. Inilah asal mula maraknya iklan-iklan yang 
menyesatkan dalam masyarakat. Tanggung jawab pelaku usaha dalam Undang-undang Perlindungan Konsumen mengandung materi yang berstruktur adalah sebagai berikut : Product Liability, Profesional Liability, Contractual Liability dan Criminal Liability. Upaya-upaya yang dapat dilakukan konsumen akibat penayangan iklan yang menyesatkan adalah sebagai berikut : Penyelesaian secara langsung kepada pelaku usaha periklanan dan penyelesaian melalui YLKI dengan cara Langsung secara lisan, Melalui surat, Melalui telepon dan melalui media massa. Sedangkan pengaduannya dengan cara Pengaduan diselesaikan dengan cara menghubungi toko, penjual, atau pelaku usaha, Pengaduan diselesaikan dengan cara penelitian laboratorium, Pengaduan diselesaikan dengan menghubungi instansi yang berwenang, Pengaduan diselesaikan dengan cukup memberikan penjelasan kepada pengadu dan Pengaduan diselesaikan dengan cara ke Pengadilan.

b. Saran

1. Perlu adanya kerjasama antara konsumen, pelaku usaha periklanan, Lembaga Perlindungan Konsumen Swadaya Masyarakat, YLKI, BPSK dan pemerintah, agar efektifitas pelaksanaan Undang-undang Perlindungan Konsumen dapat diterapkan secara maksimal di masyarakat.

2. Perlu ditingkatkan pertanggungjawaban pelaku usaha periklanan dalam mempromosikan atau mengiklankan suatu barang dan atau jasa dengan memberikan informasi yang benar, jelas dan jujur tentang barang dan atau jasa tersebutkepada konsumen serta lebih memperhatikan ketentuan-ketentuan yang ada. 
3. Memberdayakan Badan Penyelesaian Sengketa Konsumen (BPSK) yang diharapkan ditangani oleh sumber daya manusia yang lebih netral, profesional dan jujur sekaligus lebih dapat menyelesaikan masalah dibandingkan melalui proses pengadilan. 


\section{DAFTAR PUSTAKA}

\section{A. Buku :}

Dedi Harianto,2010, Perlindungan hukum bagi Konsumen Terhadap Iklan yang Menyesatkan, Bogor : Ghalia Indonesia.

Husni Syawali dan Neni Sri Imaniyati, 2000, Hukum Perlindungan Konsumen, Bandung:Mandar Maju.

Jefkins Frank, 2000, Periklanan, Jakarta:Erlangga.

Johannes Gunawan, 2001, Tanggung Jawab Pelaku Usaha Menurut Undang-undang Nomor 8 Tahun 1999 Tentang Perlindungan Konsumen, Jurnal Hukum Bisnis.

M. Jamiludin Ritongga, "Kriteri-kriteria iklan yang menyesatkan", Surat Kabar Suara Pembaharuan, 16 Maret 1999.

N.H.T. Siahaan, 2005, Hukum Konsumen : Perlindungan Konsumen dan Tanggung Jawab Produk, Jakarta:Panta Rei.

Soerjono Soekanto, 2002, Pengantar Penelitian Hukum, Jakarta : UI Press.

Yusuf Shofie,2007, Perlindungan Konsumen dan Instrumen-instrumen Hukum, Bandung:Citra aditya.

Yusuf Shofie, Sistem Tanggung Jawab dalam Periklanan, Jurnal Hukum dan Pembangunan No. 2 Tahun XXVI April 1996.

\section{B. Peraturan Perundang-undangan:}

Undang-Undang Dasar Negara Republik Indonesia Tahun 1945.

TAP MPR RI No.II/MPR/1993 tentang GBHN.

Undang-undang Nomor 8 Tahun 1999 tentang Perlindungan KonsumenKode Etik Periklanan. 